\title{
PELAKSANAAN PEMBELAJARAN TATAP MUKA TERBATAS DI KELOMPOK BERMAIN AL-LUBAWI SALATIGA
}

\author{
Ibdaul Latifah ${ }^{\text {a, } 1}$, Sri Murniyati ${ }^{\text {b, } 2}$ \\ ${ }^{\mathrm{a}, \mathrm{b}}$ Institut Agama Islam Negeri Salatiga \\ ${ }^{1}$ latifahibdaul@iainsalatiga.ac.id ; ${ }^{2}$ srimurniyati229@gmail.com
}

\author{
Informasi artikel \\ Received : \\ Januari 26, 2022. \\ Revised : \\ Februari 13, 2022. \\ Publish :
}

Maret 03, 2022.

Kata kunci:

Pelaksanaan

Pembelajaran;

Tatap Muka

terbatas;

Kelompok

Bermain

\begin{abstract}
ABSTRAK
Penelitian ini bertujuan untuk mendeskripsikan pelaksanaan pembelajaran tatap muka terbatas di Kelompok Bermain Al Lubawi Salatiga. Jenis penelitian ini adalah deskriptif kualitatif dengan teknik pengumpulan data berupa wawancara, observasi dan dokumnetasi. Sumber data yang digunakan dalam penelitian ini adalah primer dan sekunder. Data primer peneliti peroleh dari wawancara dengan kepala sekolah, guru dan orangtua peserta didik. Sedangkan data sekunder diperoleh dari dokumentasi dan arsip sekolah. Hasil penelitian menunjukkan bahwa pelaksanaan pembelajaran tatap muka terbatas berjalan dengan lancar meskipun terdapat beberapa permasalahan. Persiapan dalam melaksanakan pembelajaran tatap muka terbatas telah dilakukan oleh pihak sekolah diantaranya mengisi daftar periksa PTM terbatas dan semua pendidik serta tenaga pendidik telah melakukan vaksinasi. Pelaksanaan dilakukan dengan prosedur yang sangat ketat dan tetap mematuhi protokol kesehatan. pembatasan jumlah anak dalam satu ruang kelas hanya 5 peserta didik serta pengurangan alokasi waktu hanya 1 jam saja. Permasalahan yang timbul dalam pelaksanaan pembelajaran tatap muka terbatas adalah anak yang belum sepenuhnya menaati protokol kesehatan, kebiasaan anak yang belum disiplin dalam menghadapi sekolah serta dipersingkatnya alokasi waktu sehingga menyebabkan pemberian materi belum maksimal.
\end{abstract}

ABSTRACT
This study aims to describe the implementation of face-to-face learning in the
Al Lubawi playgroup Salatiga. This type of research is descriptive qualitative
with data collection techniques in the form of interviews, observations and
documentation. Sources of data used in this study are primary and secondary
data sources. Primary data researchers obtained from interviews with
principals, teachers and parents of students. While secondary data obtained
from documentation and school archives. The results showed that the
implementation of face-to-face learning was limited to running smoothly even
though there were some problems. Preparations for conducting limited face-
to-face meetings have been carried out by the school including filling out a
limited PTM checklist and all educators and teaching staff have vaccinated.
The implementation is carried out with very strict procedures and still adheres
to health protocols. limiting the number of children in one classroom to only
5 students and reducing the time allocation for only 1 hour. Problems that
arise in the limited face-to-face implementation are children who do not fully
comply with health protocols, the habits of children who are not disciplined
in dealing with school and the shortened time allocation causes the material
provision is not optimal.

Keywords: Implementation of Learning; Limited Faceto-face; Playgroup
This work is licensed under a Creative Commons Attribution-ShareAlike 4.0 International License. Allows readers to read, download, copy, distribute, print, search, or link to the full texts of its articles and allow readers to use them for any other lawful purpose. 


\section{PENDAHULUAN}

Pandemi Covid-19 merubah segala bentuk sektor kehidupan di dunia dari ekonomi, sosial, kesehatan, pendidikan dan lainnya. Sektor ekonomi mengalami perubahan sangat signifikan dari menurunnya product dosmetic regional bruto, berkurangnya pendapatan daerah, meningkatnya pengangguran dan angka kemiskikan dan tak kalah penting terjadinya inflasi (Anggarani \& Prastyoning, 2021). Dalam aspek kesehatan juga mengalami dampak yaitu kasus positif covid yang semakin meningkat serta adanya penuruan dalam aspek layanan kesehatan dikarenakan tenaga kesehatan memfokuskan pada penanganan covid 19 (Aeni, 2021).

Dalam sektor pendidikan pun mengalami perubahan akibat pandemi covid 19 yang berdampak dalam beberapa aspek. Perubahannya tidak hanya dalam perubahan aspek kurikulum, namun juga dalam sistem pembelajaran. Pembelajaran yang awalnya dilakukan dengan tatap muka menjadi tatap maya atau online (dalam jaringan) disebabkan tidak diperbolehkan berkerumun dalam satu kegiatan karena ditakutkan menjadi penyebab penularan covid 19. Dampak yang terjadi adalah penurunan ketercapaian tujuan pembelajaran, berkurangnya sosialisasi anak, dan menurunnya kualitas pendidikan.

Meskipun terdapat beberapa perubahan akibat covid 19, pemerintah tetap berupaya dalam menangani kasus tersebut dan juga berupaya agar sektor-sektor penting tetap berjalan sebagaimana mestinya. Dalam sektor pendidikan beberapa kebijakan telah dilakukan oleh pemerintah diantaranya pada Maret 2020 pemerintah menerapkan kebijakan belajar dari rumah. Pembelajaran yang dilakukan dirumah pun terdapat banyak kendala diantaranya sulit berkonsentrasi, keterbatasan jaringan internet, kurang bersemangat, sulit berkomunikasi dengan guru, keterbatasan waktu orangtua, belum mampu mengoptimalkan media dan tidak memiliki perangkat TIK (Minanurokhim, Haq, \& Basit, 2021). Permasalahan lain yang timbul adalah ketika pembelajaran dari rumah atau dengan online beberapa siswa tidak sungguh-sungguh memperhatikan apa yang disampaikan oleh guru mereka mengikuti pembelajaran secara online hanya untuk formalitas mengisi daftar hadir saja (Annur \& Maulidi, 2021).

Pembelajaran jarak jauh dari rumah yang dilakukan di Masa Pandemi Covid 19 juga mengalami berbagai kendala diantaranya sarana prasarana yang belum 
mendukung penggunaan teknologi pada saat pembelajaran online, lingkungan belajar dan karakteristik siswa juga sangat mempengaruhi keberhasilan dalam pelaksanaan pembelajaran (Masyitoh \& Arfinanti, 2021)

Peralihan dari pertemuan tatap muka ke pertemuan tatap maya atau pembelajaran online menyebabkan learning loss dan literacy loss (minat belajar dan membaca memudar) sehingga menurunkan kemampuan siswa lebih besar dibandingkan akibat libur sekolah (Minanurokhim, Haq, \& Basit, 2021). Dampak pembelajaran dari rumah (online) yang berkepanjangan adalah rentannya siswa putus sekolah karena keterpaksaan bekerja untuk membantu perekonomian orangtua akibat pandemic Covid -19 .

Kelompok Bermain merupakan satuan pendidikan yang termasuk dalam pendidikan anak usia dini. Pendidikan Anak Usia Dini adalah dasar atau awal dari pendidikan yang selanjutnya. Masa usia dini adalah masa dimana perkembangan anak mencapai perkembangan yang sangat optimal oleh karena itu pendidikan usia dini sangatlah penting dalam mencerdaskan anak bangsa. Pandemi Covid 19 juga berpengaruh dalam kemajuan pendidikan anak usia dini. Penurunan hasil belajar anak, kreativitas yang tidak berkembang, serta sosialisasi anak yang menurun adalah akibat dari perubahan pembelajaran dari tatap muka ke pembelajaran tatap maya. Namun menurut Munro \& Faust anak usia dini kemungkinan sangat kecil terpapar covid 19 daripada orang dewasa, selain itu anak usia dini paling banyak dirugikan dalam pembelajaran(Husna, 2022). Oleh sebab itu pertemuan tatap muka terbatas ini sangat disambut gembira bagi pengelola satuan pendidikan anak usia dini dan orangtua peserta didik dengan tetap mematuhi protocol kesehatan.

Dengan berbagai kendala, permasalahan dan dampak dalam pembelajaran di masa Pandemi Covid 19 ini pemerintah berupaya untuk menanggulanginya dengan menerapkan kebijakan baru yaitu Pembelajaran Tatap Muka Terbatas. Penerapan kebijakan tersebut juga melewati beberapa syarat salah satunya adalah pendidik dan tenaga kependidikan dalam satuan pendidikan yang ingin menyelenggarakan pembelajaran tatap muka terbatas harus sudah menjalani vaksin Covid 19 secara lengkap dan paling lambat pada tahun ajaran 2021/2022 (Kemendikbud, 2019). Dari permasalahan diatas penulis ingin mengetahui bagaimana penerapan pembelajaran 
tatap muka terbatas di satuan lembaga pendidikan anak usia dini khususnya di kelompok bermain Al Lubawi Salatiga.

\section{METODE}

Penelitian ini berjenis kualitatif deskriptif. Teknik Pengumpulan data dalam penelitian ini menggunakan wawancara, observasi dan dokumentasi. Kelompok Bermain dipilih oleh peneliti sebagai Lokasi Penelitian. Data dikumpulkan dari dua sumber data primer dan sekunder. Kepala sekolah, guru dan orangtua peserta didik menjadi sumber data primer dalam penelitian ini sedangkan dokumentasi dan arsip sekolah menjadi sumber data sekunder. Setelah data terkumpul kemudian dilakukan pengecekan keabsahan data menggunakan triangulasi sumber dengan cara membandingkan antara satu sumber dengan sumber lainnya.

\section{PEMBAHASAN}

Pandemi Covid 19 melanda Indonesia kurang lebih 2 tahun. Dalam kurun waktu tersebut penyebaran covid 19 mengalami kenaikan dan penurunan. Kenaikan terjadi karena penyebaraan yang terjadi sangatlah cepat dengan beragam faktor yang mempengaruhinya terutama faktor kerumunan orang yang tidak menghiraukan protocol kesehatan, maka dengan sangat cepat virus tersebut menyebar. Akibat kenaikan lonjakan virus maka pemerintahpun melarang masyarakat untuk berkerumun, menghentikan kegiatan sosial yang mengundang banyak masa serta merubah sistem pembelajaran dengan tatap maya.

Seiring waktu ketika masyarakat mulai sadar akan bahayanya virus covid -19 mereka dengan penuh sadar mematuhi peraturan pemerintah dengan menerapkan protokol kesehatan, menjauhi kerumunan, dan berpartisipasi dalam vaksinansi covid 19. Lambat laun virus corona menurun sehingga pemerintah mengumumkan tentang kebijakan New Normal dengan dibarengi oleh berbagai kebijakan diantaranya memperbolehkan melakukan kegiatan dengan membatasi jumla peserta, memperbolehkan pembelajaran tatap muka terbatas bagi satuan-satuan pendidikan yang telah memenuhi syarat.

Penelitian ini memaparkan informasi penerapan pembelajaran tatap muka terbatas di kelompok bermain Al Lubawi Salatiga. Informasi yang diperoleh dari persiapan, 
pelaksanaan hingga evaluasi pertemuan tata muka terbatas di kelompok bermain AlLubawi Salatiga.

\section{Persiapan Pelaksanaan Pembelajaran Tatap Muka Terbatas di Kelompok Bermain Al-Lubawi Salatiga}

Berawal dari evaluasi tentang pembelajaran dari rumah yang dilakukan oleh kelompok bermain Al Lubawi berjalan kurang maksimal karena beberapa kendala maka kepala sekolah dengan wali murid mengadakan rapat pertemuan guna membahas sistem pendidikan tentang pembelajaran tatap muka terbatas. Rapat dilakukan oleh kepala sekolah setelah melihat surat edaran dari kementerian pendidikan dan kebudayaan tentang kebijakan pembelajaran tatap muka terbatas bagi lembaga pendidikan.

Hasil dari rapat tersebut antara lain: 1) sosialisasi kebijakan pemerintah tentang pembelajaran tatap muka terbatas, 2) persetujuan orangtua pada program pembelajaran tatap muka terbatas dengan protocol kesehatan, 3) pembelajaran hanya berlangsung satu jam, 3) masing-masing anak mendapat giliran jadwal pertemuan terbatas disekolah, 4) satu kelas dibagi menjadi tiga kelompok setiap minggunya.

Sesuai dengan keputusan bersama Menteri Pendidikan dan Kebudayaan, Menteri Agama, Menteri Kesehatan dan Menteri Dalam Negeri Republik Indonesia Nomor 03/KB/2021, Nomor 384 Tahun 2021, Nomor HK.01.08/MENKES/424/2021. Nomor 440-717 Tahun 2021 Tentang panduan penyelenggaraan pembelajaran di masa pandemi covid 19, menetapkan syarat penyelenggaraan PTM Terbatas. Salah satu persyaratannya adalah kepala satuan pendidikan mengisi daftar periksa pada laman Dapodik untuk menentukan kesiapan satuan pendidikan dalam melaksanakan PTM terbatas. Kepala sekolah kelompok bermain Al Lubawi telah mengisi daftar periksa tersebut sehingga siap untuk melaksanakan PTM terbatas.

Kelompok Bermain Al Lubawi telah mengisi daftar periksa persiapan PTM Terbatas dengan bukti di Kelompok Bermain Al Lubawi telah tersedia toilet yang bersih, tempat cuci tangan dengan sabun dan sanitizer serta telah melakukan penyemprotan disinfektan. Selain itu Kelompok Bermain Al Lubawai juga sudah mempunyai alat pengukur suhu tubuh dan juga masker serta lokasinya juga dekat dengan pelayanan kesehatan. Kepala sekolah juga telah mendata bahwa tidak ada 
warga sekolah yang memiliki kondisi medis comorbid selain itu transportasi bagi peserta didik dilakukan oleh orangtua masing-masing sehingga tidak menggunakan transportasi umum yang rawan terjadi penyebaran covid 19. Yang tak kalah penting sekolah telah membuat kesepakatan bersama komite sekolah dan juga para orangtua peserta didik tentang diperbolehkannya peserta didik melaksanakan pembelajaran tatap muka terbatas.

Ketika pembelajaran tatap muka dilakukan ada tiga hal yang perlu diperhatikan, peserat didik, pendidik dan tenaga kependidika (Suryani, Tuteh, Nduru, \& Pendy, 2022). Para pendidik dan tenaga kependidikan yang berada di lingkungan sekolahpun telah melakukan vaksinasi sehingga para orangtua menyetujui tentang kebijakan pembelajaran tatap muka terbatas ini. Sarana dan prasarana juga menjadi factor pendukung penting dalam pelaksanaan pembelajaran tatap muka terbatas.

\section{Pelaksanaan Pembelajaran Tatap Muka Terbatas di Kelompok Bermain Al- Lubawi Salatiga}

Pelaksanaan Pembelajaran Tatap Muka Terbatas dimulai sesuai jadwal yaitu pukul 08.00 WIB. Sebelum pembelajaran dimulai, maka kegiatan pembiasaan baru dilaksanakan terlebih dahulu yaitu :

a) Pemeriksaan suhu badan untuk pendidik, peserta didik dan wali murid yang mengantar dengan thermogun

b) Mencuci tangan dengan sabun pada air mengalir ditempat yang telah disediakan

c) Memastikan anak memakai masker atau face shield dengan benar dan menjaga jarak ketika bersama dengan temannya

d) Menimbang berat badan, mengukur tinggi badan dan lingkar kepala anak

e) Memberi jarak tempat duduk didalam kelas

f) Guru selalu mendampingi dan mengawasi anak serta mencatat hasil pembelajaran sebagai bahan evaluasi

Pembelajaran dimulai dengan berdoa sebelum belajar, kemudian masing- masing anak dipersilahkan memilih media belajar yang telah disediakan sesuai yang disukainya. Guru menyediakan lima buah meja berisi media belajar dan bermain. Hal 
ini sesuai dengan prosedur pembelajaran tatap muka terbatas yang dibuat oleh pemerintah maka peserta didik dalam satu kelas hanya diperbolehkan maksimal 5 peserta didik dengan menjaga jarak minimal 1,5 meter. Untuk itu Kelomok Bermain Al Lubawi membuat peraturan satu kelas hanya boleh diisi oleh 5 peserta didik saja untuk peserta didik yang lainnya dijadwalkan pada pertemuan berikutnya. Hal ini sesuai dengan cohoroting yaitu pengelompokkan oeserta didik pada kelompok kecil beserta guru, sehingga mereka hanya beraktifitas pada circle yang sama (Minanurokhim et al., 2021).

Berikut contoh pembagian peserta didik disetiap harinya dalam seminggu.

Tabel 1. Jadwal Mingguan Peserta Didik

\begin{tabular}{|c|c|c|}
\hline No & Hari & Nama Peserta Didik \\
\hline 1 & Senin & Denys, Lando, Arsen, Veera, Nabila \\
\hline 2 & Selasa & David, Juna, Ara, Zahra, Hayyun \\
\hline 3 & Rabu & Salma, Raka, Anjani, Danish \\
\hline 4 & Kamis & Denys, Lando, Arsen, Veera, Nabila \\
\hline 5 & Jumat & David, Juna, Ara, Zahra, Hayyun \\
\hline 6 & Sabtu & Salma, Raka, Anjani, Danish \\
\hline
\end{tabular}

Dalam pelaksanaan pembelajaran tatap muka terbatas sekolah tetap menjalankan protokol kesehatan para pendidik menggunakan masker dan selalu mencuci tangan dengan hand sanitizer setelah memegang benda atau media pembelajaran. Guru juga selalu menjaga jarak dengan peserta didik dan teman sejawatnya. Tidak hanya dalam pelaksanaan pembelajaran protokol kesehatan juga dilakukan sebelum dan setelah pembelajaran. Sebelum pembelajaran guru harus memastikan bawa sarana dan prasarana telah dilakukan disinfeksi, memastikan tersedianya sabun cuci dan hand sanitizer, memastikan tersedianya masker, memastikan thermoghun dan selalu melakukan pemantauan kesehatan warga satuan pendidikan. Setelah pembelajaranpun guru harus memastikan semua perlengkapan keperluan yang akan digunakan untuk pembelajaran besok pagi harus siap ada ditambah dengan melaporkan hasil 
pemantauan kesehatan warga satuan pendidikan harian kepada Dinas Pendidikan setempat.

Pada pembelajaran tatap muka terbatas sekolah meniadakan adanya jam istirahat dikarenakan pembelajaran hanya berlangsung satu jam. Hal ini demi menghindari hal -hal yang tidak diinginkan juga sebagai bentuk kepatuhan terhadap peraturan pemerintah dalam pemberantasan penyebaran covid 19. Peserta didik dihimbau untuk membawa minum dan bekal sendiri ke sekolah. Setelah pembelajaran selesai peserta didik dijemput oleh orangtuanya dengan tetap memperhatikan protokol kesehatan memakai masker, mencuci tangan dan menghindari kerumunan.

\section{Evaluasi Pelaksanaan Pembelajaran Tatap Muka Terbatas di Kelompok Bermain Al-Lubawi Salatiga}

Pembelajaran tatap muka terbatas yang telah dilaksanakan menimbulkan berbagai macam permasalahan. Masalah yang sering terjadi adalah pembiasaan dalam mematuhi protokol kesehatan. Anak usia dini belum begitu memahami betul mengenai pentingnya mematuhi protokol kesehatan, sehingg perlu kerja keras dari pihak sekolah terutama guru dalam memastikan peserta didik patuh terhadap protokol kesehatan. Guru mendapatkan pekerjaan tambahan dengan sering mengingatkan tentang cuci tangan setelah memegang benda kemudian selalu membetulkan masker yang digunakan siswa apabila penggunaanya tidak benar, mengingatkan juga untuk selalu menjaga jarak baik didalam kelas maupun diluar kelas.

Tidak hanya peserta didik saja yang masih abai terhadap protokol kesehatan gurupun juga terkadang lupa menerapkan kebiasaan baru ini, sehingga perlu adanya kerjasama antar stakeholder dalam mengingatkan satu dengan yang lainnya dalam hal mematuhi protokol kesehatan. Orangtua peserta didik juga harus dijelaskan mengenai pentingnya protokol kesehatan sehingga semuanya mematuhi peraturan tersebut karena orangtua peserta didiklah yang mengantar jemput anak ke sekolah.

Selain itu permasalahan yang muncul adalah anak yang belum terbiasa dengan kebiasaan baru ketika berangkat sekolah. Setelah sekian lama anak belajar dari rumah, ketika dihadapkan dengan pembelajaran tatap muka terbatas mau tidak mau anak harus mengubah kebiasaannya, dari bangun pagi, mandi pagi, sarapan pagi dan lain 
sebagainya. Masih banyak anak yang terlambat datang ke sekolah ataupun tidak masuk sekolah karena bangun terlambat dan juga malas berangkat sekolah karena sudah terbiasa dengan belajar online dari rumah. Dalam hal ini peran orangtua sangat diperlukan guna membujuk anak untuk dapat ke sekolah kembali.

Hal lain yang tidak kalah penting adalah guru merasa pemberian pembelajaran tidaklah berjalan efektif bahkan tujuan pembelajaran belum sepenuhnya diberikan dikarenakan alokasi waktu pembelajaran yang sangat singkat sekali yaitu hanya satu jam. Sehingga guru harus pintar membagi waktu ketika memberikan apersepsi, memberikan materi dan memberikan evaluasi tindak lanjut. Proses pembelajaran tatap muka terbatas memerlukan pengelolaan pembelajaran yang baik (Johan, Halendra, \& Haderah, 2021). Tidak jarang proses pembelajaran tidak sesuai dengan yang telah direncanakan dan ditulis dalam rencana pelaksanaan pembelajaran harian (RPPH) dikarenakan waktu yang sangat singkat. Dalam pertemuan tatap muka terbatas guru dituntut untuk lebih bekerja ekstra karena tidak hanya memberikan pelajaran saja tetapi juga harus memperhatikan tingkah laku peserta didik, jika ada yang lalai dalam mematuhi protokol kesehatan maka guru harus sigap dalam mengingatkan.

Meskipun terdapat berbagai permasalahan dalam pembelajaran tatap muka terbatas, para oangtua peserta didik tetap lebih setuju dengan adanya kebijakan ini daripada pembelajaran dari rumah. Para orangtua merasa anak lebih disiplin dalam kegiatan sehari-hari, sosialisasi anakpun menjadi lebih baik dan anak lebih memahami materi yang diberikan oleh guru. Ketika pembelajaran dari rumah orangtua peserta didik kesusahan dalam memahamkan dan mendampingi anak belajar sehingga anak tidak fokus dan materi tidak dapat tersampaikan dengan baik.

Pertemuan tatap muka terbatas memerlukan kerjasama yang baik antara pendidik, peserta didik dan orangtua peserta didik. Dengan kerjasama yang baik diharapkan permasalahan-permasalahan yang muncul ketika pelaksanaan pembelajaran tatap muka terbatas dapat diatasi sebaik mungkin.

\section{SIMPULAN}

Pelaksanaan pembelajaran tatap muka terbatas yang dilaksanakan oleh Kelompok Bermain Al Lubawi berjalan lancar meskipun menemui permasalahan. Dari awal persiapan pelaksanaan dengan meminta persetujuan dari para orangtua dan komite 
sekolah, kemudian mengisi daftar periksa persiapan PTM Terbatas serta para pendidik dan tenaga kependidikan telah melakukan vaksinasi. Pada pelaksanaanya Kelompok Bermain Al Lubawi menerapkan protokol kesehatan yang telah diatur oleh pemerintah dengan mengatur jarak siswa, membatasi jumlah siswa dalam kelas yaitu maksimal 5 anak serta alokasi waktu pembelajaran yang dipersingkat yaitu satu jam. Pada tahapan evaluasi pelekasanaan Pembelajaran Tatap Muka Terbatas Kelompok Bermain Al Lubawi mengalami berbagai permasalahan diantaranya, anak yang belum sepenuhnya menaati protokol kesehatan, kebiasaan anak yang belum disiplin dalam menghadapi sekolah serta dipersingkatnya alokasi waktu menyebabkan pemberian materi belum maksimal. Walaupun mengalami permasalahan, banyak orangtua peserta didik yang lebih setuju dengan kebijakan PTM Terbatas dibandingkan dengan pembelajaran dari rumah. Untuk meyukseskan pembelajaran tatap muka terbatas maka perlu kerjasama yang baik antara pendidik, tenaga pendidik, peserta didik dan orangtua peserta didik.

\section{UCAPAN TERIMA KASIH}

Terima kasih peneliti ucapkan kepada pihak-pihak terkait dalam penelitian ini terutama kelompok bermain Al-Lubawi Salatiga. serta pengelola jurnal ABATA yang telah menerbitkan artikel ini.

\section{REFERENSI}

Aeni, N. 2021. Pandemi Covid-19 : dampak Kesehatan, Ekonomi, dan Sosial. Jurnal Litbang, 17(1), 17-34

Anggarani, A., \& Prastyoning, W. 2021. Dampak Pandemi Covid 19 Terhadap Sektor Ekonomi Berimbas Pada Tingginya Angka Perceraian Di Wilayah Kabupaten Bogor. Jurnal Abdimas, 7(3).

Annur, F., \& Maulidi, A. 2021. Pembelajaran Tatap Muka di Tengah Pandemi Covid19: Studi Kasus pada Madrasah Aliyah Nurul Huda Pekandangan Barat. Maharot: Journal of Islamic Education, 5(1), 17-36.

Husna, M. 2022. Eksplorasi Penerapan Pembelajaran Tatap Muka Terbatas pada Jenjang PAUD di Masa Kebiasaan Baru. 6(3), 1846-1858. https://doi.org/10.31004/obsesi.v6i3.1814

Johan, H., Halendra, \& Haderah. 2021. Analisis Sistem Manajemen Pembelajaran Tatap Muka Pada Masa Pandemi Covid 19 di STIE EL Hikam. 3(3), 310-315.

Kemendikbud. 2019. Buku Saku Panduan Penyelenggaraan Pembelajaran Di Masa Pandemi Coronavirus Disease 2019. 2019.

Masyitoh, D., \& Arfinanti, N. 2021. Analisis Pelaksanaan Pembelajaran Tatap Muka Terbatas (PTMT) Pada Era New Normal Terhadap Hasil belajar Matematika Siswa Madrasah Aliyah. Sigma : Jurnal Pendidikan Matematika, 13, 160-167. Minanurokhim, M. A., Haq, N. Y. I., \& Basit, A. 2021. Panduan Aman Pembelajaran Tatap Muka Terbatas (Cetakan 1). Jakarta: Direktorat Jenderal Pendidikan Anak Usia Dini Pendidikan Dasar dan Pendidikan Menengah Kementerian Pendidikan 
dan Kebudayaan.

Nurani, Y. 2013. Konsep Dasar Pendidikan Anak Usia Dini (cetakan ke). Retrieved from https://news.ddtc.co.id/strategi-pendidikan-pajak-untuk-anak-usia-dini11555

Purba, E. F., \& Simanjutak, P. 2012. Metode Penelitian (edisi kedua). Medan: Sadia.

Raco, J. (2010). Metode Penelitian Kualitatif ( Jenis, Karakter dan Keunggulanya). Jakarta: PT Grasindo.

Sidiq, U., \& Choiri, M. M. 2019. Metode Penelitian Kualitatif di Bidang Pendidikan. In M. A. Dr. Anwar Mujahidin (Ed.), Journal of Chemical Information and Modeling (Vol. 53). Retrieved from http://repository.iainponorogo.ac.id/484/1/

Sugiyono. 2013. Metode Penelitian Kuantitaif,Kualitatif dan R\&D. In Alfabeta.

Suryana, D. 2013. Pendidikan Anak Usia Dini (Teori dan Praktik Pembelajaran) (T. E. U. Press, ed.). Padang: UNP Press Padang.

Suryani, L., Tuteh, K. J., Nduru, M. P., \& Pendy, A. 2022. Analisis Implementasi Pelaksanaan Pembelajaran Tatap Muka Terbatas di Masa New Normal. 6(3), 2234-2244. https://doi.org/10.31004/obsesi.v6i3.1915

Sutarman. 2016. Manajemen Pendidikan Anak Usia Dini. Bandung: Pustaka Setia. 